\title{
ASSESSMENT OF THE RAPID TEST BASED ON AN IMMUNOCHROMATOGRAPHY TECHNIQUE FOR DETECTING ANTI-Treponema pallidum ANTIBODIES
}

\author{
Neuza Satomi SATO(1), Carmen Silvia de MELO(1), Lia C.M.S. ZERBINI(1), Edilene P.R. SILVEIRA(1), Luiz Jorge FAGUNDES(3) \& Mirthes UEDA(2)
}

\begin{abstract}
SUMMARY
A rapid test based on an immunochromatography assay - Determine ${ }^{\mathrm{TM}}$ Syphilis TP (Abbott Lab.) for detecting specific antibodies to Treponema pallidum was evaluated against serum samples from patients with clinical, epidemiological and serological diagnosis of syphilis, patients with sexually transmitted disease other than syphilis, and individuals with negative serology for syphilis. The Determine $^{\mathrm{TM}}$ test presented the sensitivity of $93.6 \%$, specificity of $92.5 \%$, and positive predictive value and negative predictive value of $95.2 \%$ and $93.7 \%$, respectively. One serum sample from patient with recent latent syphilis showed a prozone reaction. Determine ${ }^{\mathrm{TM}}$ is a rapid assay, highly specific and easy to perform. This technique obviates the need of equipment and its diagnostic features demonstrate that it may be applicable as an alternative assay for syphilis screening under some emergency conditions or for patients living in remote localities.
\end{abstract}

KEYWORDS: Syphilis; Treponema pallidum; Immunochromatography assay; Antibody; Rapid test.

\section{INTRODUCTION}

Definitive diagnosis of syphilis has been difficult because of the inability to cultivate Treponema pallidum subsp. pallidum in vitro. Serological tests are pivotal for laboratory screening and diagnosis of syphilis, and they fall into two categories: non-treponemal and treponemal tests. The former detect cardiolipin antibodies and include Venereal Disease Research Laboratory (VDRL) and Rapid Plasm Reagin (RPR) tests, and both are used as screening test for syphilis as well as for treatment follow up. However, the specificity of these cardiolipin - based tests is not very high, therefore nonspecific reactions are observed in some clinical or physiological conditions. Moreover, the sensibility is lower at initial stage of primary syphilis and late period of disease (tertiary syphilis) in comparison with the secondary syphilis. The treponemal tests such as FTA-abs, passive hemaglutination (TPHA) or enzymelinked-immunosorbent assay (ELISA) using T. pallidum antigens are used as a confirmatory test ${ }^{5,11,14}$.

All these tests require laboratorial facility to perform, and also some period of time to obtain results. In this context, the availability of a test with high specificity, easy to perform with reduced operator handling time and providing rapid result would be interesting to be used in situations of emergency or for screening of maternal and/or newborn at moment of delivery, mainly in cases of pregnant women who have not screened at antenatal care follow up. This format of test may also be useful in outpatient clinics where some patients have difficulty in returning for further consultation.
The Rapid Plasm Reagin (RPR) "teardrop" card assay for fingerprick blood samples developed in 60' was the first serological test for screening of syphilis, which could be applied in field conditions without the conventional laboratory equipments ${ }^{8}$. DYCK et al. $(1993)^{1}$ evaluated the performance of the RPR "teardrop" test with plasma obtained from finger-prick of 466 pregnant women, and the authors observed lower diagnostic features of the RPR "teardrop" test in comparison to the classical RPR performed with serum.

There are several other rapid tests using cardiolipin ${ }^{3}$ or treponemal ${ }^{6,15}$ antigens, including a latex agglutination test using a purified Treponema pallidum antigen ${ }^{6}$ or recombinant antigen ${ }^{15}$, and a DOT assay using cardiolipin as antigen and revealed with protein A complexed with colloidal gold ${ }^{3}$. The results of latex test are obtained in 10 minutes using automated system or in two minutes for DOT assay, and it has been reported $^{3}$ that they provide reliable diagnostic performance, but they have not yet been commercially available in our country.

Recently, a new test kit Determine ${ }^{\mathrm{TM}}$ (Abbott Diagnostic, Chicago, IL, USA) for diagnosis of syphilis was introduced on the market. This is an immunochromatographic-based rapid test using treponemal antigen, which does not require any equipment and the result can be obtained in 15 minutes.

In the present study, we report the diagnostic performance of the test kit Determine ${ }^{\mathrm{TM}}$ in the study of serum samples from patients with syphilis, patients with sexually transmitted disease (STD) other than 


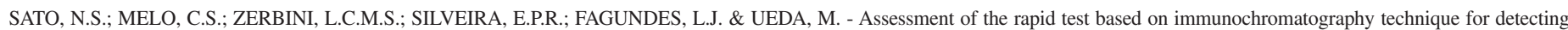
anti-Treponema pallidum antibodies. Rev. Inst. Med. trop. S. Paulo, 45(6):319-322, 2003.

syphilis, seronegative individuals in syphilis serology assays, and clinically healthy individuals.

\section{MATERIAL AND METHODS}

Serum samples: A total of 125 serum samples were studied, comprising: 63 serum samples from patients with clinical, epidemiological and laboratorial diagnosis of syphilis; 24 samples from patients with STD other than syphilis, including cancre (2), gonorrhea (4), non-gonorrheal ulcer (4), condiloma (10), herpes (1), candidiasis (2) and trichomoniasis (1); 38 serum samples presenting negative results by serological tests for syphilis. Serum samples from patients with syphilis and from patients with STD other than syphilis were collected from individuals who were referred to the Department of Sanitary Dermatology of School of Public Health/University of São Paulo (USP), São Paulo, SP, Brazil, after signing the informed consent form. Serum samples presenting negative results by serological tests for syphilis (28) were selected from diagnostic routine work of the Department of Serology/Institute Adolfo Lutz, São Paulo, SP, Brazil and sera from healthy blood donors (10) who were referred to the Pro-Sangue Foundation (Blood Bank) of São Paulo/Faculty of Medicine/ University of São Paulo.

Serological tests for syphilis: For establishing the serological status for syphilis, serum samples were analyzed by means of the following tests: VDRL (Behring, Marburg, Germany); FTA-abs (Wama Diagnostica, São Carlos, SP, Brazil); TPHA (Organon-Teknika, Akzo Nobel, Boxtel, Netherland); Captia Syphilis-M (Centocor, Malvern, PA, USA); ELISA IgA, IgM and IgG for syphilis (Randox Laboratories, Creemlin, UK). All of the assays were performed according to the respective manufacture's recommendations.

Determine $^{\text {TM }}$ Syphilis TP (Abbott Diagnostic, Chicago-IL, USA.): a qualitative assay for detecting anti-Treponema pallidum antibodies is based on an immunochromatography technique, and its reagent kit is presented in format of cards for individual testing. The inert solid support is divided into three regions: region 1, with an absorbent support for sample application (sample pad); region 2, corresponding to the sample result display (patient window site); and region 3, corresponding to the control reaction (control window site). Sample is added to the sample pad, which contains the red colored complex, that is, T. pallidum antigenselenium colloid conjugate. This mixture migrates through the solid phase to the immobilized Treponema pallidum antigens at the patient window site, and moving towards to the control window site.

If anti-treponemal antibodies are present in the sample, the antibodies bind to the Treponema pallidum antigen - selenium colloid conjugate and to the T. pallidum antigen immobilized at the region 2, forming a red line at the patient window site. The excess of free antigen-selenium colloid conjugate continues migrating to the region 3 where the red line corresponding to the control is formed. If anti-treponemal antibodies are absent in the sample, the T. pallidum antigen-selenium colloid flows past the region 2, and in this case the red line is formed only in the control window (region 3 ). The presence of red line at control window is essential for assay validity. Thus, the presence of red line at regions 2 and 3 in the patient and control windows, indicates positive result, while the presence of red line at region 3 (control window) only indicates a negative result. The assay is considered invalid in absence of red line at control window.
For conducting the present study, the test was performed according to the manufacture's recommendations. Briefly, $50 \mu \mathrm{L}$ of neat undiluted serum was applied to the sample pad, marked by the arrow symbol. The results were read within 15 minutes and repeated after 24 hours by five technicians in a double-blind manner. The parameters of sensibility, specificity and efficiency were calculated according to procedures described by GALEN \& GAMBINO ${ }^{2}(1975)$, and 95\% confidence interval (CI) according to the method described by ROTHMAN \& BOICE $^{9}$ (1982).

\section{RESULTS AND DISCUSSION}

None of 125 serum samples analyzed in this study presented a "not valid" result by the Determine ${ }^{\mathrm{TM}}$ test. The assay yielded rapid results, it was easy to perform without any specialized equipment. However depending on the samples, the result interpretation was not easy due to the personal subjectivity. According to the criteria established by manufacturer, the presence of any red line, irrespective of its intensity even being faint, is considered as positive reaction. Thus, there were some difficulties in discriminating the reactivity of some samples by five technicians who were conducing the assay.

Two samples which were considered weakly positive by Determine ${ }^{\mathrm{TM}}$ test presented negative results in 15 minutes reading, and a faint red line after 24 hours. One of these samples (identified as PS-34) was from a patient with clinical diagnosis of late latent syphilis, showing however negative result by VDRL and positive result by treponemal tests (FTAabs, TPHA).

Another sample (identified as PS-22) from a patient with clinical diagnosis of early latent syphilis presented positive results by VDRL (1:32), FTA-abs, TPHA and total $\gamma$-ELISA, but negative result by IgM capture ELISA. For better evaluation, this serum sample was diluted to $1: 2$ and $1: 8$ and analyzed again by Determine ${ }^{\mathrm{TM}}$ test. At dilution $1: 2$ the reactivity pattern was the same as undiluted sample, but strongly positive at dilution 1:8. Therefore, the occurrence of prozone phenomenon was detected. Prozone reaction may take place in an immunochromatographybased assay owing to the high antibody level in the serum, and it could result in an excess of free antibodies after generating a complex with selenium colloidal-antigen conjugate. As free antibodies present higher migration speed than complexed antibodies, they should be captured by immobilized antigen located at patient window. Consequently, all of the epitope sites of the immobilized T. pallidum antigen would be blocked, just at the site where the complex seleniun colloid-antigen-antibody complex would bind to produce a red colour band. Thus, in the presence of excess of antibodies in the serum sample, the result could be interpreted as negative, because of the absence of red color line at the sample window site.

The sensibility limit of the Determine ${ }^{\mathrm{TM}}$ was evaluated by OSHIRO et $a .^{7}$ (1999), and these authors performed dilutions of serum sample with positive results for treponemal antibodies in TPLA - a latex agglutination treponemal test (Mediace) with value of 47.1 titre unit (TU). Positive reaction was detected in dilution up to $23.5 \mathrm{TU}$ at $15 \mathrm{~min}$, 19.2 TU at $30 \mathrm{~min}, 14.3 \mathrm{TU}$ at 60 minutes or 24 hours. Their data suggest that for samples with low level of antibodies, the time of 15 minutes could be short to accomplish the migration and retention of the complex antigen-selenium colloid-antibody in enough amount to form a visible 
red line at the sample window site. Hence, the reaction reading time should be reconsidered during the performance of the assay, in account of some clinical samples presenting very low level of specific antibodies depending on disease stage.

Although sensitivity of $100 \%$ is desirable for screening tests, this study showed a sensitivity of $93.7 \%$ for Determine ${ }^{\mathrm{TM}}$ test (Table 1 ). Analysis of CI $95 \%$ showed no significant difference between Determine $^{\mathrm{TM}}$ and other treponemal tests (FTA-abs and TPHA) (Table 2). Antibodies in the undiluted serum sample from patient PS-22 was not detected by this assay and negative results were observed by every treponemal serologic test in four other samples from patients with early latent or late latent syphilis (Table 2).

Three serum samples from 24 patients with STD other than syphilis showed positive results by Determine ${ }^{\mathrm{TM}}$ test, and two of them also presented reactivity by classical treponemal tests. The first sample from a patient with clinical diagnosis of gonorrhoea (PS-86) presented positive results by classical treponemal tests, but negative by ELISA-IgM and VDRL. The second sample from a patient with herpes (PS-46) presented positive results by TPHA and total $\gamma$-ELISA, and also by Determine ${ }^{\mathrm{TM}}$ test; and the third one from a patient with chancre had positive results by Determine $^{\mathrm{TM}}$ test only. Based on these results, the specificity of the Determine $^{\mathrm{TM}}$ test was $95.2 \%$. False positive results for treponemal tests

Table 1

Reactivity of Rapid Test (Determine ${ }^{\mathrm{TM}}$ Syphilis TP - Abbott Lab) in serum samples from individuals with syphilis and from subjects presenting negative results on classical antibody detecting tests for syphilis, and qualitative parameters

\begin{tabular}{lcc}
\hline Dignostic parameter & $\%$ & $(\mathrm{~N} /$ Total N) \\
\hline Sensitivity & 93.7 & $(59 / 63)$ \\
Specificity & 95.2 & $(59 / 62)$ \\
Positive predictive value & 95.2 & $(59 / 62)$ \\
Negative predictive value & 93.7 & $(59 / 63)$ \\
Concordance & 94.4 & $(118 / 125)$ \\
\hline
\end{tabular}

are rare, however, false-positive results should be associated with viral infection or mixed connective tissue and autoimmune disease ${ }^{13}$. The overall concordance for Determine ${ }^{\mathrm{TM}}$ was $94.4 \%$; positive predictive value and negative predictive value were $95.2 \%$ and $93.7 \%$, respectively (Table $1)$.

In spite of Determine ${ }^{\mathrm{TM}}$ assay being a rapid and easy to perform, its result interpretation may occasionally be subjective and difficult. The assay can be applicable as screening test in emergency conditions or in pregnant women at delivery time who have not carried out an adequate prenatal care, but it should be considered that the sensibility may be lower when antibodies level is extremely high or too low.

According to the Law $774 / 97^{10}$ of December 20, 1999, laboratory testing for the detection of HIV and syphilis antibodies has been compulsory for every antenatal screening carried out at the public and private service of health in the São Paulo State. Thus, this rapid test may be a helpful tool for laboratory diagnosis in the attempt to break off the transmission chain of congenital syphilis.

It is fundamental to carry out the investigation of syphilis at delivery in pregnant women who have not been followed at antenatal care. The conventional serological tests for syphilis are usually time consuming, and commonly the mother and its newborn leave hospital even before the results of serological tests are reported. A rapid test like Determine ${ }^{\mathrm{TM}}$ may be useful to overcome these limitations.

It is noteworthy to point towards the occurrence of prozone reaction demonstrated in this treponemal test, in a condition of strongly reactive serum sample. Then, initially this kind of serum sample may show an atypical weakly reactivity, or in some occasions a negative "rough" reaction with undiluted serum. It is well known that serum samples containing large amount of antibodies may occasionally demonstrate a prozone phenomenon in the nontreponemal serologic testing ${ }^{4,12}$, which may be not perceived by an inexperient technician. Thus, in performing the Determine ${ }^{\mathrm{TM}}$ test, all tests with faint or atypical reaction should be reanalyzed after diluting serum (at 1:2, 1:8 and so on), in order to obtain the proper optimal antibody concentration, providing a detectable reactivity.

Table 2

Comparison of Rapid test (Determine $\mathrm{T}^{\mathrm{TM}}$ - Abbott) results with classical serological tests used for screening and diagnosis

\begin{tabular}{|c|c|c|c|c|c|c|c|c|c|}
\hline \multirow[b]{2}{*}{ Group } & \multirow[b]{2}{*}{ (n) } & \multicolumn{2}{|c|}{ Determine $\mathrm{T}^{\mathrm{TMa}}$} & \multicolumn{2}{|c|}{ FTA-abs ${ }^{\mathrm{a}}$} & \multicolumn{2}{|c|}{ TPHA $^{\mathrm{a}}$} & \multicolumn{2}{|c|}{ VDRL $^{b}$} \\
\hline & & Pos & Neg & Pos & Neg & Pos & Neg & Pos & Neg \\
\hline Secondary Syphilis & 12 & 12 & 0 & 10 & 02 & 11 & 01 & 10 & 02 \\
\hline Recent Latent Syphilis & 28 & 27 & 01 & 27 & 01 & 27 & 01 & 21 & 07 \\
\hline Late Latent Syphilis & 23 & 20 & 03 & 20 & 03 & 20 & 03 & 16 & 07 \\
\hline STD other than syphilis & 24 & 03 & 21 & 01 & 23 & 02 & 22 & 0 & 24 \\
\hline $\begin{array}{l}\text { Negative serological } \\
\text { results for syphilis }\end{array}$ & 38 & 0 & 38 & 0 & 38 & 0 & 38 & 0 & 38 \\
\hline$\overline{\text { Sensibility (CI 95\%) }}{ }^{\mathrm{c}}$ & & \multirow{2}{*}{\multicolumn{2}{|c|}{$93.7 \%(84.4-97.9 \%)$}} & \multicolumn{2}{|c|}{$90.5 \%(80.3-96.0 \%)$} & \multicolumn{2}{|c|}{$92.1 \%(82.3-97.0 \%)$} & \multicolumn{2}{|c|}{$74.6 \%(62.0-84.4 \%)$} \\
\hline Specificity (CI 95\%) & & & & \multicolumn{2}{|c|}{$98.4 \%(91.2-100 \%)$} & \multicolumn{2}{|c|}{$96.8 \%(88.7-99.4 \%)$} & \multicolumn{2}{|c|}{$100 \%(94.0-100 \%)$} \\
\hline
\end{tabular}

a - treponemal assay; b- nontreponemal assay; c- ROTHMAN, K.J. \& BOICE, J.D., $1982{ }^{9}$. 


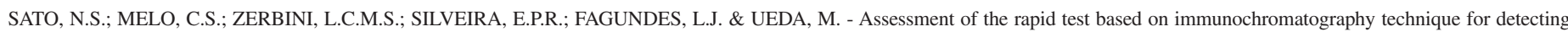
anti-Treponema pallidum antibodies. Rev. Inst. Med. trop. S. Paulo, 45(6):319-322, 2003.

\section{RESUMO}

\section{Avaliação do teste rápido para a detecção de anticorpos anti- Treponema pallidum baseado na técnica de imunocromatografia}

O desempenho do teste rápido imunocromatográfico de procedência comercial Determine ${ }^{\mathrm{TM}}$ Syphilis TP (Abbott Lab.) para detectar anticorpos específicos contra antígenos treponêmicos foi avaliado com soros de pacientes tendo diagnóstico epidemiológico, clínico e laboratorial de sífilis, de pacientes com outras doenças sexualmente transmissíveis e de indivíduos clinicamente sadios ou com resultados negativos nos testes sorológicos para sífilis. Os valores de sensibilidade e de especificidade do teste Determine ${ }^{\mathrm{TM}}$ foram respectivamente de 93,6\% e $95,2 \%$, o valor preditivo positivo foi de $95,2 \%$ e o valor preditivo negativo $93,6 \%$. O fenômeno de prozona foi observado em uma amostra de paciente com sífilis recente latente. O teste é de fácil e rápida execução, sem necessidade de equipamentos e o resultado pode ser obtido em 15 minutos, que de acordo com suas características diagnósticas poderá ser utilizado como teste alternativo de triagem em determinadas situações de emergência ou em pacientes que vivem em locais remotos.

\section{ACKNOWLEDGEMENTS}

The authors are thankful to Abbott Diagnostic in Brazil for providing Determine $^{\mathrm{TM}}$ Syphilis TP reagent kits, to Dr. Amadeo Saez Alquézar from Pro-Sangue Foundation (Blood Bank) of São Paulo, Faculty of Medicine, University of São Paulo for providing seronegative samples from blood donors, and to Dr. Sumie Hoshino Shimizu for helpful advices on statistical analysis of results.

\section{REFERENCES}

1. DYCK, E. van; VELDEN, L. van; NDOYE, I.; PIOT, P. \& MEHEUS, A. - Evaluation of the rapid plasm reagin "teardrop" card test for screening of syphilis in the field conditions. Sex. transm. Dis., 20: 194-197, 1993.

2. GALEN, R.S. \& GAMBINO, S.R. - Beyond normality: the predictive value and efficiency of medical diagnosis. New York, John Willey, 1975.
3. HUANG, Q.; LAN, X.; TONG, T. et al. - Dot-immunogold filtration assay as a screening test for syphilis. J. clin. Microbiol., 34: 2011-2013, 1996.

4. JURADO, R.L.; CAMPBELL, J. \& MARTÍN, P.D. - Prozone phenomenon in secondary syphilis. Has its time arrived? Arch. intern. Med., 153: 2496-2498, 1993.

5. LARSEN, S.A.; STEINER, B.M. \& RUDOLPH, A.H. - Laboratory diagnosis and interpretation of tests for syphilis. Clin. Microbiol. Rev., 8: 1-21, 1995.

6. MATSUMOTO, M.; ISHIKAWA, F.; MATSUBAYASHI, T. et al. - Latex agglutination test for detecting antibodies to Treponema pallidum. Clin. Chem., 39: 1700-1705, 1993.

7. OSHIRO, M.; TAIRA, R.; KYAN, T. \& YAMANE, N. - Laboratory-based evaluation of DainaScreen TPAb to detect specific antibodies against Treponema pallidum. Rinsho Biseibutshu Jinsoku Shindan Kenkyukai Shi., 10: 27-32, 1999.

8. PORTNOY, J.; BREWER, J.H. \& HARRIS, A.D. - Rapid plasma reagin (RPR) card test for syphilis and other treponematoses. Publ. Hith. Rep. (Wash.), 77: 645-652, 1962.

9. ROTHMAN, K.J. \& BOICE, J.D. - Epidemiologic analysis with programmable calculator. Boston, Epidemiology Resources, 1982. p. 24-32.

10. SÃO PAULO (ESTADO) - Lei 10.449 de 20 de dezembro de 1999. Diário Oficial do Estado de São Paulo 21 de dezembro de 1999, Seção I.

11. SINGH, A.E. \& ROMANOWSKI, B. - Syphilis: review with emphasis on clinical, epidemiologic, and some biologic features. Clin. Microbiol. Rev., 12: 187-209, 1999.

12. SPANGLER, A.S.; JACKSON, J.H.; FIUMARA, N.J. \& WARTHIN, T.A. - Syphilis with a negative blood test reaction. J. Amer. med. Ass., 189: 87-90, 1964.

13. SPARLING, P.F. - Diagnosis and treatment of syphilis. New Engl. J. Med., 284: 642653, 1971.

14. WICHER, K.; HOROWITZ, H.W. \& WICHER, V. - Laboratory methods of diagnosis of syphilis for the beginning of the third millennium. Microbes Infect., 2: 1035-1049, 1999.

15. YOUNG, H.; MOYES, A.; de Ste CROIX, I. \& McMILLAN, A. - A new recombinant antigen latex agglutination test (Syphilis Fast) for the rapid serological diagnosis of syphilis. Int. J. STD AIDS, 9: 196-200, 1998.

Received: 4 August 2003

Accepted: 29 October 2003 